\title{
Bio-perceptions of Hydro carbon contaminated soil and its Bioremediation effect with Biological Consortia
}

\author{
Aswathy Chandran ${ }^{1}$ and S. Sujatha ${ }^{2}$ \\ ${ }^{1}$ M. Phil-Research Scholar, Department of Biotechnology, MCC, Mariagiri, India \\ ${ }^{2}$ Assist.Professor, Depmt of BT, Malankara Catholic College, Mariagiri, India \\ Corresponding Author: S. Sujatha
}

\begin{tabular}{l} 
Article Info \\
\hline Article history: \\
Received 25 September 2020 \\
Received in revised form 29 \\
September 2020 \\
Accepted 3 October 2020 \\
\hline Keywords: \\
Allothonous Bacterial Strain \\
Organic Waste \\
Growth Performance \\
Bacterial Species \\
Antagonic Activity \\
Bioremediation
\end{tabular}

\begin{abstract}
The present research work has clearly denoted as initially estimation of physic-chemical properties of the experimental hydrocarbon contaminated soil. The texture of the soil plays a very important role in microbial and plant species establishment and development and also influences physical parameters of the soil. The current results are clearly showed experimental soil of the hydrocarbon contaminated soil possessed totally eight different autochthonus bacterial strains were provably identified viz., Acinetobacter, Mycobacterium sp., Bacillus sp., Pseudomonas sp., and Aeromonas sp., observed by Bergy's Manual. When this experimental soil was remediated with two biological sources such as four allothonus bacterial strains named as Enterobacter sp., Flavobacter sp., Shigella sp., and Bacillus sp., along with agronomic wastes also addition with neem juice. From the present result showed that Enterobacter sp., subjected polluted soil was remediated maximum than other treated sources assessed by spectrometric data. While, the biofilm formation experiment also been definitely expressed biodegradation potential enriched allothonus bacterial strain was the following order Enterobacter sp., Flavobacter sp., Shigella sp., and Bacillus sp.,. Moreover, other interesting finding also had been profounded such as dominant Antagonistic activity potential possessed autochthonus bacterial strain from the hydrocarbon contaminated soil. It has been identified through the molecular identification those typical organism expressed the named as 'Pseudomonas aeruginosa PA96' by 16sr RNA sequence analysis. Additionaly maximum and maximum antagonistic activity has been noticed on E.coli, more or less similar zone of inhibition showed on other bacterial species of Shijella sp., and K. pneumonia.
\end{abstract}

\section{Introduction}

Industrial development, population growth, urbanization and a disregard for the environmental consequences of releasing chemicals into the environment all contributed to the modern pollution situation (Amadi et al., 1993). Previously, (Abed et al., 2002) portrayed over 2 billion tons of petroleum is produced annually worldwide. Spillages of oil have become a common occurrence. Depending on the site location, the level of oil contaminants in the soil may be as high as 10\% (w/w) (Gogoi et al., 2003). Before, Atlas \& Philp, (2005) depicted the large quantities of hazardous substances are carelessly disposed of in the environment and are thus creating enormous pollution problems in soils and waters around the world. Petroleum compounds are considered to be recalcitrant to microbial degradation and persist in ecosystems because of their hydrophobic nature and low volatility and thus they pose a significant threat to the environment (Abed et al., 2002; Atlas \& Philp, 2005). Protective and preventive measures need to be taken into account to avoid spillage into the 
environment (Singh \& Lin., 2005). Bio-augmentation is defined as the addition of pollutantdegrading microorganisms to augment the bio-degradative capacity of indigenous microbial populations (Zhang et al., 2013). Hence the aim of augmentation is to improve the fertility status of such soils and to enhance the rate of oil degradation finally improving the nutrients of the experimental soil for crop production. Due to its toxicity, widespread presence and complex nature, this type of pollution is a serious problem, one reason being that as the modern civilization (Wyszkowski and Ziolkowska,2004). The major points of soil pollution with refinery products are petrol stations garages and other areas of petroleum based products (Bidoia et al., 2010). The soil in polluted soil will plug the soil pores, affecting the permeability of soil aeration causing changes in soil nutrient status, so that carbon and nitrogen ratio and phosphorus to phosphorus ratio, causing changes in soil microbial communities, soil erosion micro-ecological environment (Lu et al., 2003),. At this stage, the research on oil- contaminated soils mainly focuses on the oil pollution on plant growth (Li et al., 2007; Shi, et al., 2013), soil physical and chemical properties (Ogbo, 2009) petroleum pollution ecological risk assessment (Liu et al., 2007) and petroleum pollution bioremediation (Faulkner \& Lochmiller, 2002). Oil pollution has been reported to have harmful effects on agricultural lands and crops (Agbogidi and Nweke, 2005).

\section{Methodology}

\section{Sample Collection}

Aged hydrocarbon contaminated soil samples were collected from subsurface of twenty five years old kerosene vender site, located in Nellimoodu, Trivandrum, India whereas for control, uncontaminated garden soil was used. At both the sites, 10 top and sub-soil samples were collected randomly within a 0.5 meter quadrate and mixed into a composite sample representative of particular with a sterile spatula into a sterile polyethylene bag and taken to the laboratory immediately where stones in the samples were removed, the soils were homogenized through a $2 \mathrm{~mm}$ sieve and stored in the dark bottles till further analysis. All the parameters were carried out in triplicates and averages of three readings were considered.

\section{Treatment of the Contaminated Soil}

The petroleum contaminated soil was treated with four different type of microbes, they are klebshilla, Shigella, Enterobactor Sp., Flavobactor. And this process was continued for one month. And again this soil was treated with organic waste with water and organic waste with neem juice and polluted soil with distilled water. And this process was continued for one month.

\section{Biofilm Formation of Petroleum Contaminated Soil Microbes}

The bacterial isolates were grown overnight in nutrient broth at $37^{\circ} \mathrm{C}$. Aliquots of $3 \mu \mathrm{l}$ were inoculated in 30 parallel wells of a 96 well micro titer plate. Then the plate was incubated period, the well were rinsed with physiological saline to remove the detached cells and fixed with $2 \mu 1$ of $99.99 \%$ ethanol for 10 minutes, the attached $2 \mu 1$ of crystal violet $(2 \%)$ for 20 minutes. The plates were rinsed with distilled water and amounts of attached cells were observed.

HPLC analysis:

A portion of TPH is subjected to column chromatography using silica gel as stationary phase (re-activated at $180^{\circ} \mathrm{C}$ for $4 \mathrm{~h}$ ). The first solvent is n-hexane for elution of saturates then using benzene to obtain aromatics which are subjected to HPLC. The studied HPLC instrument model Agilent 1200 series equipped with photodiode array detector is used for 
identification and quantification of 16 PAHs present in extracted oil using gradient method. The used column is SUPELCOSIL LC-PAH $(15 \mathrm{~cm} \times 4.6 \mathrm{~mm}, 5 \mu \mathrm{m})$, sample size $2.0 \mu \mathrm{L}$, mobile phase (Acetonitril: Water) HPLC grade (gradient program), mobile phase program 50:50\% (v/v) for $1 \mathrm{~min}, 100 \%$ Ace at $20 \mathrm{~min}$, for $15 \mathrm{~min}$, then 50:50\% again at $35 \mathrm{~min}$, flow rate $1.0 \mathrm{~mL}$ minG1. The identification of PAHs peaks is established by a chromatographic reference mixture of 16 PAHs standards of known composition listed by USEPA (1998).

\section{Molecular Identification by 16srrna Sequence Analysis}

Procedure:-

An isolated white turbidity DNA lysate of GIVEN EXPERIMENTAL SAMPLE DNA was prepared as follows. Two microliters of lytic enzyme solution from the Puregene DNA Purification Kit (Flowgen) was added to each sample, which was then briefly mixed and incubated at $37^{\circ} \mathrm{C}$ for 30 to $45 \mathrm{~min}$. Samples were pelleted and resuspended in $100 \mu \mathrm{l}$ of sterile distilled water, boiled for $10 \mathrm{~min}$, and then stored at $-20^{\circ} \mathrm{C}$ until required. Ten microliters of sample was used as a template in each PCR.

PCR amplification.

PCR amplification was performed in a volume of $50 \mu$ consisting of $5 \mu$ of concentrated lysate or $10 \mu \mathrm{l}$ of $1: 10$ and 1:100 dilutions of the lysate in sterile MilliQ-grade water (Millipore, Boston, Mass.). The remainder of the reaction mixture contained $1 \times$ PCR buffer (50 mMKCl, 10 mMTris-HCl [pH 9.0], 0.1\% Triton X-100, 1.5mM MgCl2), 0.4mM each of the four deoxynucleoside triphosphates (dATP, dCTP, dGTP, and dTTP), 1.0 U of Taq DNA polymerase (Promega UK Ltd., Southampton, United Kingdom) and $0.2 \mu \mathrm{M}$ (each) PCR primer. Thirty-five microliters of DyNAwax was used to separate the primers and lysate from the rest of the reaction mixture to reduce the incidence of nonspecific PCR products and also improve the yield of the desired DNA fragments. The PCR was performed in an Omni-Gene thermal cycler (Hybaid, Teddington, United Kingdom). The cycling conditions were as follows: (i) an initial denaturation step at $94^{\circ} \mathrm{C}$ for $5 \mathrm{~min}$; (ii) 35 cycles, with 1 cycle consisting of denaturation at $94^{\circ} \mathrm{C}$ for $1 \mathrm{~min}$, annealing at $55^{\circ} \mathrm{C}$ for $1 \mathrm{~min}$, and extension at $72^{\circ} \mathrm{C}$ for $1.5 \mathrm{~min}$; and (iii) a final extension step at $72^{\circ} \mathrm{C}$ for $10 \mathrm{~min}$. Positive and negative controls were included in every set of PCRs performed. The positive control was a standard reaction mixture containing $10 \mathrm{ng}$ of bacterial DNA instead of sample, whereas the negative control contained sterile water instead of sample. Reaction products were either analyzed immediately or stored at $-20^{\circ} \mathrm{C}$ until required. The mixed 16SrRNA gene products were ligated into the PCR2.1-TOPO vector (Invitrogen BV, Groningen) and transformed into TOP10 cells (Invitrogen) according to the manufacturer's instructions

\section{Results and Discussion}

The current research was initially depicted as the texture of the soil plays a very important role in microbial and plant species establishment and development and also influences physical parameters of the soil result were shown on Table 1a and $b$. The kerosene contaminated soil had greater clay content $36.22 \%$, sand content $35.46 \%$ and silt content of $28.31 \%$, as compared to clay, sand and silt content of $32.4 \%, 42.4 \%$ and $25.2 \%$ respectively in the uncontaminated garden soil. Both the soils were classified as Clay Loam. The higher percentage of clay and silt in the kerosene contaminated soil suggests a reduction in soil aeration and porosity where porosity was encountered $64.47 \%$ as compared to $69.95 \%$ in the uncontaminated garden soil, which could affect crop productivity, yield and growth The moisture content for contaminated and uncontaminated soils was $11.49 \%$ and $18.094 \%$ respectively (Table 1). Moreover, Moreover, the same hydrocarbon contaminated 
soilexperimental soil was subjected through quantitatively analysis as a result, totally eight different bacterial strains were isolated as autochthonous. Among the eight maximum (37.38) and minimum (4.36) bacterial organisms are isolated followed by optimum level (12.08, $12.15,11.23$ and 10.61) total autochthonous bacterial organisms were noticed Fig-1

Fig:2a Depicted the before treated polluted soil chromatogram by HPLC technique. Totally 40 differ hydrocarbon fractions of chemical compounds approved in the original 20 years polluted sample. It was clearly replicated heavy contaminated oil of petroleum and diesel constituents with various peak level along with different extinction time extent from 0.52 to $130 \mathrm{mt} / \mathrm{s}$. Interestingly after treated with allothonous bacterial strain polluted soil possessed quantity on number of compounds are drastically reduce from 40 to 24 represented on Figure:2b. Though, peak level also visibly seen gradually decreased from normalised signal of the previous without remediated soil to after treated remediated polluted soil. Moreover, Agronomic wastes treated polluted soil expressed total 21 compounds, it was significantly twenty fold decreased diminished from the original pollutant rushed soil.

Table 2: Growth performance of V. unguiculata clearly revealed that root length, leaf length, number of leaves and breadth of the leaf represented significantly increased after remediated soil with agronomic waste than before treated contaminated soil. Secondly when allothonous bacterial subjected contaminated soil develop plant clearly showed than minimum range of growth has been noticed towards leaf- root length and stem length also. From the resulted table was clearly noticed that significant growth performance observe after treated or remediated with Agronomic waste than original polluted soil. Among the two sources of remediated soil definitely expressed better growth performance has been noticed on Agronomic waste than allothonous bacterial species. Even though among the four various allothonous bacterial strains treated contaminated soil developed legume plant was betterment effect noticed than the other three bacterial species than Flavobacter sp, Shigella sp., Klebsiella sp.,

Table 3: indicated Antagonistic activity of hydrocarbon contamination of soil origin bacterial strains of Psedomonousaeruginosa p.96 against the pathogenic organisms represented on the table number-6. From the present result reflected the interesting remarkable maximum zone of inhibition noticed on E.coli (1.7 \pm 0.10$)$ followed by second most highest zone of inhibition noticed on Shigella species $(1.18 \pm 0.57)$ and least $(0.98 \pm 0.022)$ activity noticed against Klebsiella pneumonia apart from the result clearly showed significantly maximum antagonistic activity against E. coli be noticed compared that commercialized antibiotic drugs like Nystatin (1.0 \pm 0.72$)$ Gentamycin. Moreover, Fig-3 shows the metabolite identification of the antagonistic specific bacteria with maximum zone of inhibition noticed bacterial strain such as E. coil. From the present result totally three analytes or metabolites named as Inosine -diposphate, Methyl-6-methylamino Staurosporine and 1, 3 Di-Quinolinate along with its retention time viz., 348, 405 and 608 respectively (Table 4).

The topological parameters of the biofilm architecture also highlight the inherent properties of these films. The mean thickness and average biomass calculated from confocal imaging software correlated with the current research expressed biofilm assay result.The thickness and biomass were highest level noticed on Enterobacter sp., followed by Flavobacter sp., and whereas they were least thickness has been noticed on both bacterial strain of Bacillus sp., and Shigella sp., respectively. From the result it was evident that the multicellular aggregation was significantly higher in presence of crude oil. The greater skewness value of the poor biofilm forming strain Enterobacter sp., makes the film more porous. The higher standard deviation relates the higher heterogeneity of the biofilm for the all the three strains 
(Fig 4). From the hydrocarbon polluted soil origin dominant bacterial strain as well as antagonistic potential bacterial species has been identified through molecular technique of by 16srRNA sequence analysis. This result depicted PCR product specific banding nucleotide sequence typically $551 \mathrm{Kbp}$ along with its conformatory phylogenetic tree diagram also been revealed and idententified that organism named as Pseudomonas aeruginosa PA96.

Germination of legume seed V. unguiculata before and after remediated with two various sources of bacterial strains and organic waste on the polluted soil was noted in table 4. Remarkably polluted soil taken nine days prolonged when compound with control soil. Moreover other experimental sources like organic waste with neem juice and other bacterial organisms. Such as Shigella, Klebsshillasp. ,Enterobactter sp., Flavobacter sp. Subjected polluted soils clearly denoted 7 and 8 days taken for germination,. It was moreover equal days observed (8day) and seven days when treated with Shigella, Klebshilla sp., Enterobactor and Flavobacter sp., respectively (Fig-5).

Table 1. Physicochemical properties of hydrocarbon contaminated soil

\begin{tabular}{|c|c|c|c|c|}
\hline S.NO. & $\begin{array}{l}\text { Analyzed } \\
\text { Parameters } \\
\text { In the soil }\end{array}$ & $\begin{array}{l}\text { Control } \\
\text { Soil }\end{array}$ & $\begin{array}{c}\text { HC } \\
\text { Contaminated } \\
\text { Soil }\end{array}$ & Processed soil \\
\hline 1. & $\mathbf{P H}$ & 7.3 & 5.1 & 6.7 \\
\hline 2. & Phosphorus & 652 & 403 & 472 \\
\hline 3. & Nitrogen & 1.34 & 9.35 & 8.92 \\
\hline 4. & Ammonium & 1108.8 & 145.6 & 1124.9 \\
\hline 5. & Potassium & 60 & 23 & 58 \\
\hline 6. & chloride & 61 & 60 & 60 \\
\hline 7. & sulfur & 1139 & 904 & 1147 \\
\hline 8. & Iron & 65 & 42 & 69 \\
\hline 9 & Zinc & 30 & 11 & 35 \\
\hline 10 & Manganese & 7 & 3 & 10 \\
\hline 11. & Copper & 4.71 & 2.03 & 7.63 \\
\hline 12. & Aluminum & 255 & 154 & 204 \\
\hline 13. & Sodium & 90.61 & 55.23 & 56.87 \\
\hline 14. & Calcium & 34.11 & 13.36 & 15.76 \\
\hline 15. & Magnesium & 142.42 & 67.53 & 69.77 \\
\hline 16 & As & - & 10.01 & 8.7 \\
\hline 17. & Boron & 0.2 & 0.001 & 1.65 \\
\hline 18 & $\begin{array}{c}\text { No. of bacterial } \\
\text { population }\end{array}$ & 5 & 5 & 7 \\
\hline
\end{tabular}

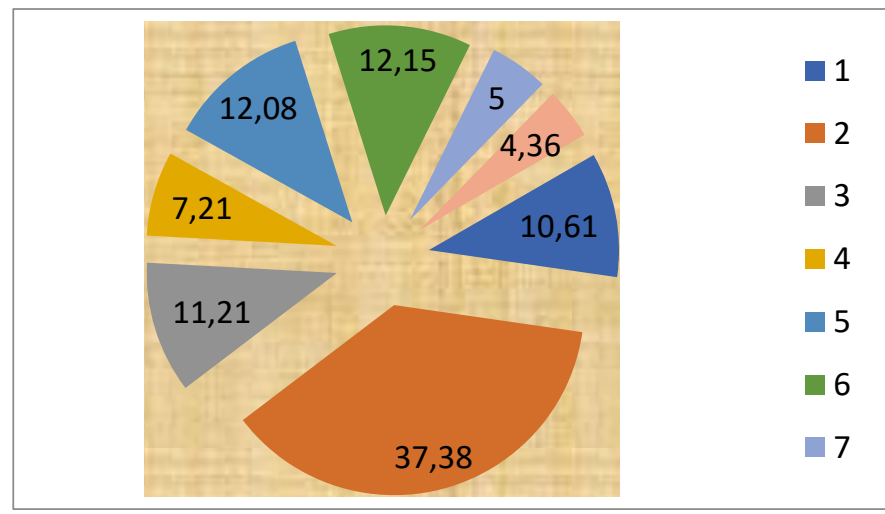


Figure 1. Total Autochthonous Bacterial populations from the Hydrocarbon contaminated soil
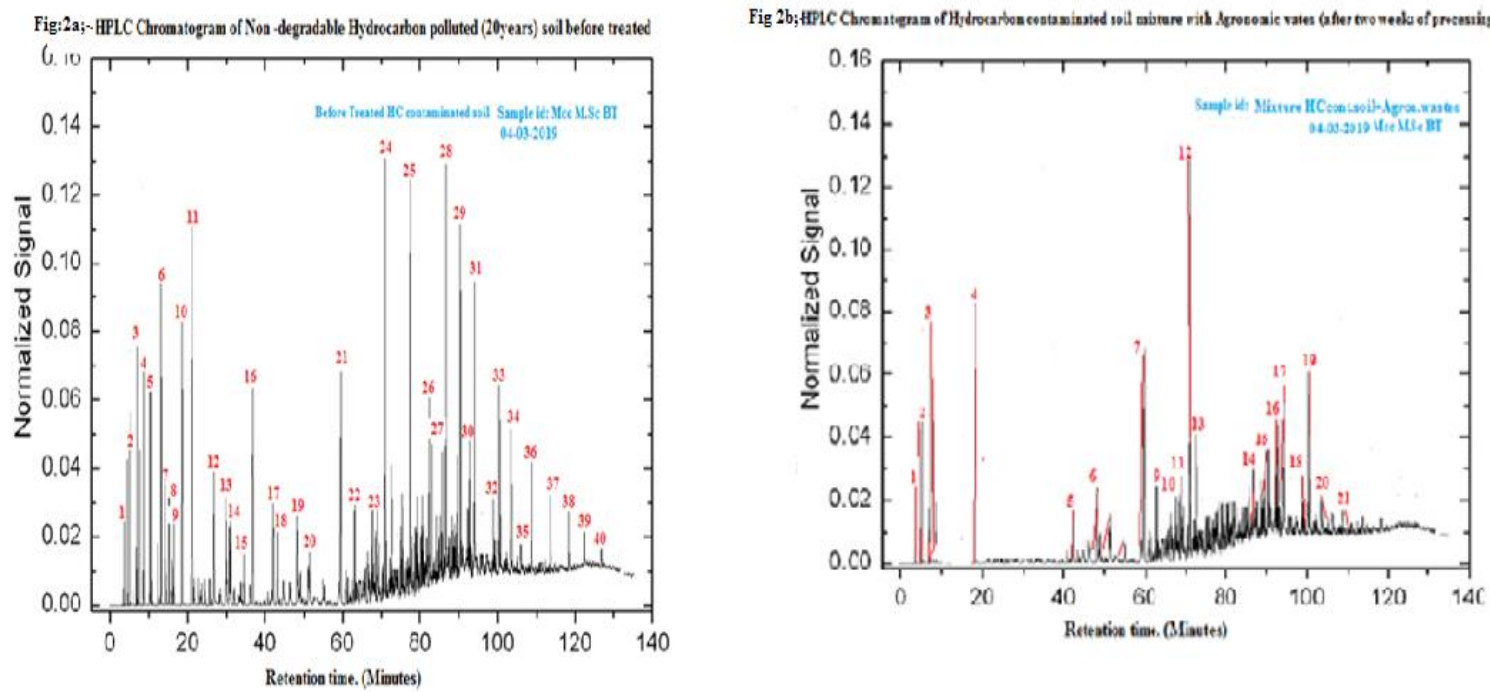

Table 2. Growth performance of Vigna unguiculata (Linn) in after remediated Hydrocarbon contaminated soil (four weeks).

\begin{tabular}{|cc|ccc|}
\hline S. NO. & Parameters & $\begin{array}{c}\text { Control } \\
(\mathbf{c m})\end{array}$ & $\begin{array}{c}\text { HC } \\
\text { ContaminatedSoil }\end{array}$ & $\begin{array}{c}\text { After Remediated } \\
\text { Soil }\end{array}$ \\
\hline 1. & Root length & $9.27 \pm 0.72$ & $0.63 \pm 0.20^{* *}$ & $2.30 \pm 0.85^{*}$ \\
\hline 2. & Leaf length & $4.26 \pm 0.23$ & $1.21 \pm 0.07^{*}$ & $1.65 \pm 0.11$ \\
\hline 3. & No. of leaves & $17.15 \pm 0.34$ & $19.46 \pm 0.14^{*}$ & $10.17 \pm 0.34^{*}$ \\
\hline 4. & Stem length & $3.82 \pm 0.56$ & $4.92 \pm 0.04^{* *}$ & $1.69 \pm 0.21^{\text {is }}$ \\
\hline 5. & Leaf breadth & $1.74 \pm 0.75$ & $0.11 \pm 0.01$ & $0.55 \pm 0.02$ \\
\hline
\end{tabular}

Table 3. Antagonistic activity of Hydrocarbon contaminated soil origin bacterial strain of P.aeruginosa PA96 against the pathogenic organism

\begin{tabular}{|c|c|c|c|c|}
\hline \multirow{2}{*}{$\begin{array}{c}\text { Name of the } \\
\text { experimental } \\
\text { organism }\end{array}$} & \multicolumn{4}{|c|}{ Experimental Organisms } \\
\cline { 2 - 5 } & E.coli & Klebsiella pneumonea & Shigella sp., & Bacillus Sp., \\
\hline P.aeruginosa PA96 & $1.7 \pm 0.10^{*}$ & $0.98 \pm 0.022$ & $1.18 \pm 0.57^{* *}$ & $0.11 \pm 0.021$ \\
\hline Nystatin & $1 . \pm 0.72$ & $1.1 \pm 0.034$ & $0.86 \pm 0.421$ & $0.58 \pm 0.025^{* *}$ \\
\hline Gentamycin & $1.0 \pm 0.031^{* *}$ & $1.5 \pm 0.05$ & $1.21 \pm 0.08^{*}$ & $1.1 \pm 0.13^{*}$ \\
\hline
\end{tabular}

* --Indicates level of significant at $\mathrm{P}<0.05 \%$

**--Indicates level of significant at $\mathrm{P}<0.001 \%$

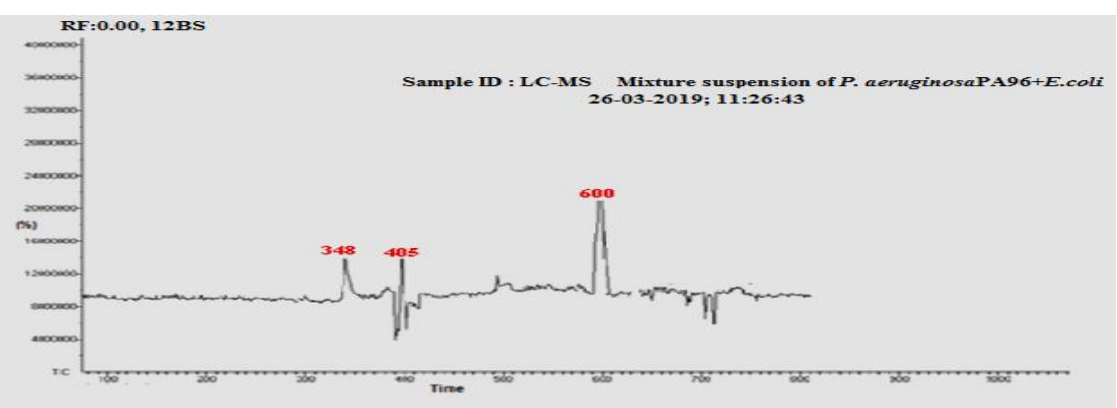


Figure 3. LCMS Chromatogram for metabolites Identification of Bacterial suspension with P. aeruginosa plus E.coli

Table 4. Bioactive compound elucidation of the Bacterial suspension with $\mathrm{P}$. aeruginosa plus E.coli by LC-MS technique

\begin{tabular}{lllllll}
\hline $\begin{array}{l}\text { S. } \\
\text { No. }\end{array}$ & Name of the Analyte(s) & $\begin{array}{l}\text { \% of } \\
\text { Peak area }\end{array}$ & $\begin{array}{l}\text { M-ole. } \\
\text { Formula }\end{array}$ & Mol. Wt & $\begin{array}{l}\text { Peak } \\
\text { Area }\end{array}$ & $\begin{array}{l}\text { Retention } \\
\text { Time }\end{array}$ \\
\hline 1. & Inosine -diposphate & 150002 & $\mathrm{C}_{10} \mathrm{H}_{12} \mathrm{~N}_{4} \mathrm{O}_{5}$ & 268.22608 & 13562387 & 348 \\
2. & $\begin{array}{l}\text { Methyl-6-methylamino } \\
\text { Staurosporine }\end{array}$ & 150000 & $\mathrm{C}_{26} \mathrm{H}_{24} \mathrm{~N}_{4} \mathrm{O}_{3}$ & 466.65 & 14955412 & 405 \\
3. & 1, 3 Di-Quinolinate & 230000 & $\mathrm{C}_{9} \mathrm{H}_{7} \mathrm{~N}$ & 129.16 & 23681475 & 608 \\
\hline
\end{tabular}

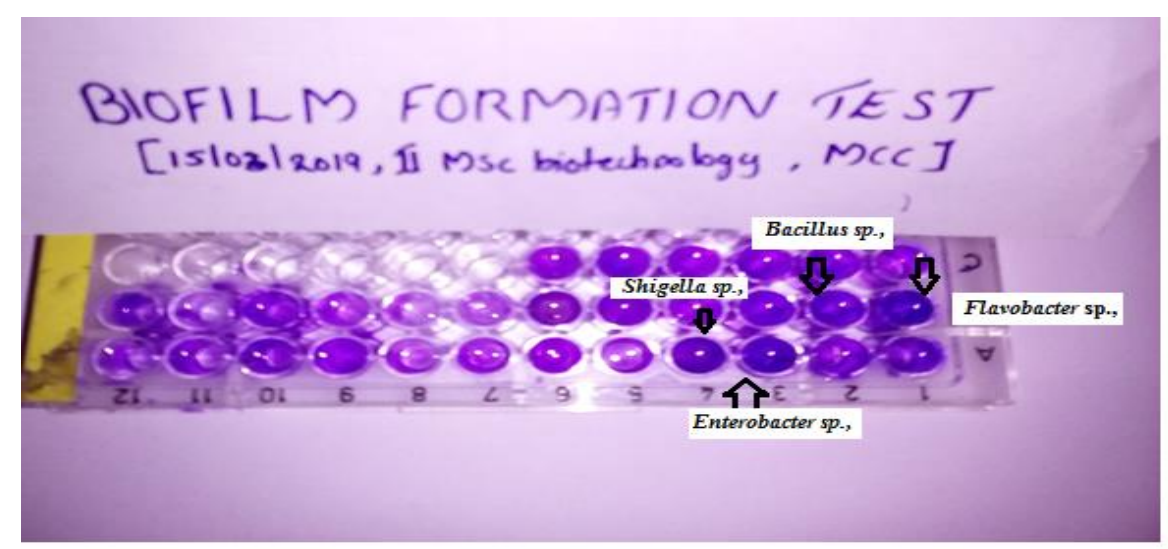

Figure 4. Biofilm Formation the treated three different hydrocarbon degraded bacterial species
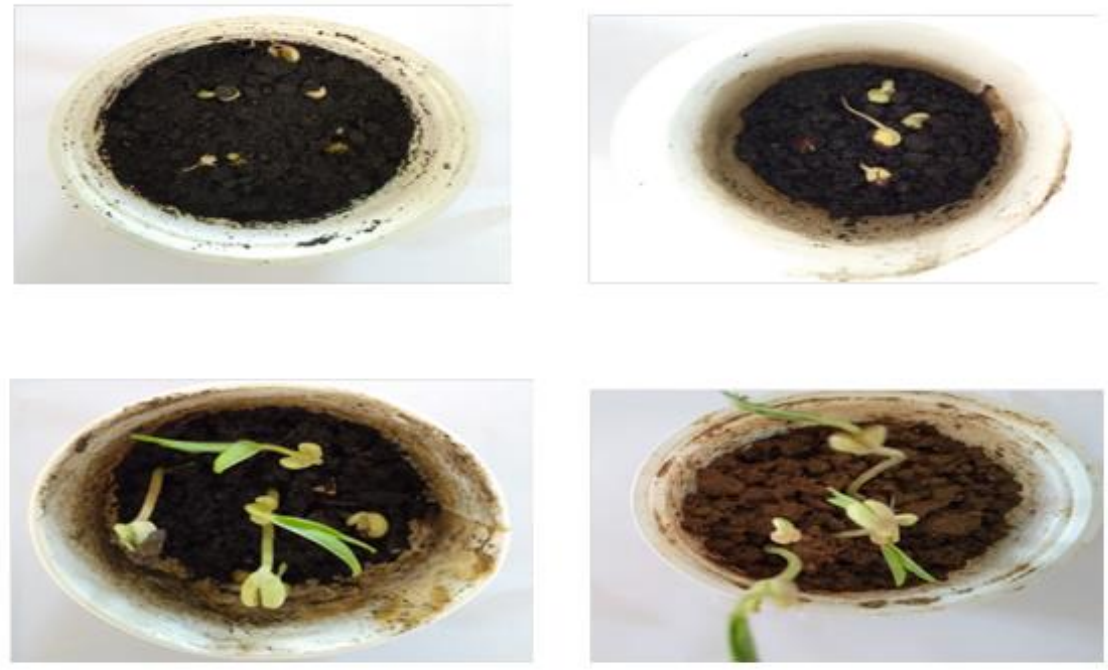

Figure 5. Germination and growth performance of Legume plant of V. unguiculara (L.) in hydrocarbon contaminated and organic waste treated various three soils (third day after treatment)

To date, extensive research has focused on oil bioremediation using pure cultures or mixed bacterial consortia isolated from oil spilled soils. However, only few studies have been reported on the different bacterial communities and diversity in soils, which were contaminated at different times of oil exposure (Dos Santos et al., 2011; Sutton et al., 2013). Previously, several researchers were opined the similar agreed view towards the present 
research findings such as probable eight more bacterial distribution in the hydrocarbon pollutant soil, it is interesting to find that many dominant species detected in the contaminated samples were related to oil-degrading strains, such as Acinetobacter, Mycobacterium sp., Bacillus sp., Pseudomonas sp., and Aeromonas which corresponds with previous reports (Deziel et al., 1996)

In this study the total petroleum hydrocarbon (TPH) encountered in kerosene contaminated automobile site were $17,510 \mathrm{mg} / \mathrm{kg}$ and $142.65 \mathrm{mg} / \mathrm{kg}$ for uncontaminated garden soil. The high TPH is as a result of kerosene contamination. These concentrations of the TPH can make soil conditions unsatisfactory for plants and microbial growth (Dejong, 1980). This concentration of contamination will also increase the presence of toxic materials such as cresol, phenols, chlorine which might inhibit the growth of the hydrocarbon oxidizers (Shi et al., 2013). As the texture of the soil plays a very important role in microbial and plant species establishment and development and also influences physical parameters of the soil (Tang, 2014). The kerosene contaminated soil had greater clay content $36.22 \%$, sand content $35.46 \%$ and silt content of $28.31 \%$, as compared to clay, sand and silt content of $32.4 \%$, $42.4 \%$ and $25.2 \%$ respectively in the uncontaminated garden soil.

The upperfraction of clay and silt in the kerosene contaminated soil suggests a reduction in soil aeration and porosity where porosity was encountered $64.47 \%$ as compared to $69.95 \%$ in the uncontaminated garden soil, which could affect crop productivity previously the similar kind of opinion was described by Adam \& Duncan (1999) yield and growth The moisture content for contaminated and uncontaminated soils was $11.49 \%$ and $18.094 \%$ respectively. This kind of similar results also been opined by Lipińska et al., (2013). The low moisture contents of contaminated soils are due to the presence of hydrocarbons and PAHs which cause an increase in soil hydrophobicity and therefore leading to decrease in the moisture holding capacity of soil (Battersby, 2000) affirms high hydrocarbon levels affect both aboveground and subterranean flora and fauna, which are essential adjuncts in the biogeochemical cycle that affects availability of plant nutrients (Wyszkowska et al., 2002).

In general, plants require 16 essential elements for growth, 13 received from the soil, three of which (N, P, and $\mathrm{K})$ constitute the primary macro-nutrients. The soil fertility indices show the concentrations of extractable macronutrients $\mathrm{P}$ and $\mathrm{K}$ in the kerosene-impacted soil were significantly lower than in uncontaminated garden soil. This could be due to free hydrocarbons in the soil but more likely to utilize the nutrients by resident micro flora. Researcher (Smith et al., 2006) opined that it is unlikely that the oil release is directly responsible for loss of macronutrients.

The current research results showed higher percentage value of nitrogen $6.12 \mathrm{mg} / \mathrm{kg}$ in kerosene contaminated soil and $1.53 \mathrm{mg} / \mathrm{kg}$ in uncontaminated soil which corroborated with the findings of (Sutton et al., 2013), who studied the biochemical and physical characterization of diesel contaminated soil in southeastern Nigeria. The increase could be derived from the nitrogen content of the refined kerosene fuel (Slavica et al., 2003). High amount of organic carbon and organic matter in the contaminated soil samples could be due to kerosene fuel which is composed of hydrocarbon and PAHs (Atlas, 1981). The present study also had been agreed with the similar observation. Commercial microbial remediation of hydrocarbon and crude oil- contaminated soils is an emerging technology involving the application of bio surfactants (Van Hamme.et al., 2003). Hydrocarbon degradation by indigenous microbial populations is the main mechanism employed (Atlas \& Bartha, 1992), because the performance of enhanced degradation through the addition of prepared microbial inocula (bio augmentation) has been ambiguous (Atlas, 1991; Li et al., 2007). 


\section{Conclusion}

In conclusion, of the present research work has clearly denoted as initially estimation of physic-chemical properties of the experimental hydrocarbon contaminated soil. While, the biofilm formation experiment also been definitely expressed biodegradation potential enriched allothonus bacterial strain was the following order Enterobacter sp., Flavobacter sp., Shigella sp., and Bacillus sp., remarkably. One of the dominant bacterial strains were it has been identified through the molecular identification those typical organism expressed the named as "Pseudomonas aeruginosa PA96" P.by 16sr RNA sequence analysis was confirmed by confocal microscopy technique. The results in the present study consolidate our finding that potent hydrocarbon degrading bacterial consortia exist naturally in the soil. It significantly reduced the spectrum of the total hydrocarbon derivatives when it compared with before treatment of the contaminated soils. This could be equally applicable for any allothonously present or other bacterial strains ubiquitously available in nature, and the technology could be further developed for targeting of any pollutants present on earth creating enormous environmental and health hazards.

\section{Acknowledgement}

First I would like to acknowledge to Malankara Catholic College Principal, Coorespondent and Biotechnology staff members, Lab assistant for providing the facility of this manuscript preparation.

\section{References}

Abed, R. M., Safi, N. M., Köster, J., De Beer, D., El-Nahhal, Y., Rullkötter, J., \& GarciaPichel, F. (2002). Microbial diversity of a heavily polluted microbial mat and its community changes following degradation of petroleum compounds. Applied and Environmental Microbiology, 68(4), 1674-1683.

Adam, G., \& Duncan, H. J. (1999). Effect of diesel fuel on growth of selected plant species. Environmental geochemistry and health, 21(4), 353-357.

Amadi, A., \& Odu, C. T. I. (1993). Effect of simulated chemical Demulsifer (Separal NF. 36 and Servo (. 6602) contamination of soil, on carbon dioxide Evolution and shifts in microbial population in a fresh water mangrove Ecosystem. International Journal of Biochemphysics, 2, 1-2.

Atlas, R. M., \& Philp, J. (2005). Bioremediation. Applied microbial solutions for real-world environmental cleanup. ASM press.

Atlas, R. M. (1991). Microbial hydrocarbon degradation-bioremediation of oil spills. Journal of Chemical Technology \& Biotechnology, 52(2), 149-156.

Atlas, R. M., \& Bartha, R. (1992). Hydrocarbon biodegradation and oil spill bioremediation. In Advances in microbial ecology (pp. 287-338). Springer, Boston, MA.

Battersby, N. S. (2000). The biodegradability and microbial toxicity testing of lubricantssome recommendations. Chemosphere, 41(7), 1011-1027.

Bidoia, E. D., Montagnolli, R. N., \& Lopes, P. R. M. (2010). Microbial biodegradation potential of hydrocarbons evaluated by colorimetric technique: a case study. Appl Microbiol Biotechnol, 7, 1277-1288. 
Bispo, A., Jourdain, M. J., \& Jauzein, M. (1999). Toxicity and genotoxicity of industrial soils polluted by polycyclic aromatic hydrocarbons (PAHs). Organic Geochemistry, 30(8), 947-952.

Ogbo, E. M. (2009). Effects of diesel fuel contamination on seed germination of four crop plants-Arachis hypogaea, Vigna unguiculata, Sorghum bicolor and Zea mays. African Journal of Biotechnology, 8(2).

Faulkner, B. C., \& Lochmiller, R. L. (2000). Increased abundance of terrestrial isopod populations in terrestrial ecosystems contaminated with petrochemical wastes. Archives of Environmental Contamination and Toxicology, 39(1), 86-90.

Lipińska, A., Kucharski, J., \& Wyszkowska, J. (2013). Urease activity in soil contaminated with polycyclic aromatic hydrocarbons. Polish Journal of Environmental Studies, 22(5).

Shi, T. F., Liu, Z. W., Tian, N., LI, J., Chen, X., \& Wang, G. B. (2013). Potential influences of petroleum pollution on soil and legume Shrubs and grasses in the Loess Area [J]. Acta Agrestia Sinica, 2, 295-301.

Singh, C., \& Lin, J. (2010). Bioaugmentation efficiency of diesel degradation by Bacillus pumilus JLB and Acinetobacter calcoaceticus LT 1 in contaminated soils. African Journal of Biotechnology, 9(41), 6881-6888.

Smith, M. J., Flowers, T. H., Duncan, H. J., \& Alder, J. (2006). Effects of polycyclic aromatic hydrocarbons on germination and subsequent growth of grasses and legumes in freshly contaminated soil and soil with aged PAHs residues. Environmental pollution, 141(3), 519-525.

Sutton, N. B., Maphosa, F., Morillo, J. A., Al-Soud, W. A., Langenhoff, A. A., Grotenhuis, T., \& Smidt, H. (2013). Impact of long-term diesel contamination on soil microbial community structure. Applied and environmental microbiology, 79(2), 619-630.

Tang, J. C. (2014). Ecological restoration techniques and principles of petroleum polluted soil. Beijing: Science Press.

Van Hamme, J. D., Singh, A., \& Ward, O. P. (2003). Recent advances in petroleum microbiology. Microbiology and molecular biology reviews, 67(4), 503-549.

Liu, W. X., Luo, Y. M., Teng, Y., Li, Z. G., \& Wu, L. H. (2007). Eco-risk assessment \& bioremediation of petroleum contaminated soil II. Changes in physico-chemical properties and microbial ecology of petroleum contaminated soil. Acta Pedologica Sinica, 44(5), 848-853.

Wyszkowska, J., Kucharski, J., \& Waldowska, E. (2002). The influence of diesel oil contamination on soil enzymes activity. Rostlinna Vyroba, 48(1), 58-62.

Zhang, X. Y., LI, K. R., \& Zhang, L. J. (2013). Effect of petroleum contamination on physical and chemical properties of soils in oilfield of northern Shaanxi. Research of soil and Water Conservation, 20(3), 32-38. 